\title{
Deadline Katy Chevigny
}

T ike many documentaries, Big Mouth's documentary "Deadline" shifted course many times during its making. The director and cinematographer Kirsten Johnson and I had decided to collaborate on a film project about capital punishment, and we wanted to offer a fresh perspective on a thorny topic that had been the subject of many other films. We knew how difficult it was to get permission to film in courtrooms and in prisons, but we didn't want to make a film that consisted entirely of so-called "talking heads", such as lawyers explaining casework. So we puzzled over a new approach.

Our first idea was to tell the story of a significant episode in the history of capital punishment, the 1972 Furman v. Georgia Supreme Court decision, which had temporarily abolished the death penalty nationwide. We planned to do some research to follow what happened to the more than 600 people who had their sentences commuted to life without parole. After some initial research, in the fall of 2002 we traveled to Mississippi, Alabama and Georgia to interview former death row prisoners and others involved in the Furman decision. One of our advisers for the film, George Kendall, recommended that we include some contemporary story element to contrast with the Furman story. "There's a lot of interesting things going on in Illinois right now", he reminded us.

We were aware of the developing story in Illinois, but hadn't intended to include it in our film. The background was this: Governor George Ryan had walked into office in 1999 only to discover that a lot of innocent people on Death Row had been wrongly convicted. And it was his job to authorize executions for those sentenced to death. Early in Ryan's term as governor, Anthony Porter was found to be innocent just two days before he was supposed to have been executed. Illinois had executed 12 people since the reinstitution of the death penalty in 1977 but had been forced to release 13 people because of new evidence. Ryan was dismayed by these facts, and in 2000 he had put a moratorium on executions, while also appointing a state commission to review the system and make recommendations. How did all this fit into our film about Furman? We had no idea, and as far as we were concerned, it didn't.

Coming back from Atlanta in 2002, I got a phone call from a friend who worked in public radio in Chicago, who said, "Aren't you making a film about the death penalty? Why aren't you here filming these hearings the Governor set up?" In his last months in office, Ryan asked the Illinois 
parole board to hold special extrajudicial hearings to review each of the 167 clemency claims of the people on Illinois' Death Row. It was news to us that the hearings were open to cameras, but we were well aware of the rarity of getting permission to film anything related to a capital punishment trial, so it piqued our interest. At the last minute, while the hearings were underway, Kirsten and I flew to Chicago for three days to film them and see if we could make anything of it. It was the documentarian's hunger for unusual access that was what ultimately motivated us. Filming something like a death penalty trial? Too good an opportunity to pass up.

It turned out that the way that the clemency hearings were set up was inherently dramatic, not to mention unprecedented and therefore historic. Ryan asked that the parole board hold an individual hearing for each of the 167 people currently on Death Row in Illinois. The parole board gave each case one hour, which was divided into 30 minutes for the prosecution and 30 minutes for the defense. From a film-making standpoint, it was pretty much a dream scenario: all the most salient and dramatic details of each case were distilled down to sixty minutes of contrasting argument and storytelling. We filmed for 3 days, 18 hearings, and had more than enough material for several complicated documentaries. The hearing room was often packed: with media, with family members of the victims as well as the prisoners' families, on occasion. Appellate lawyers and D.A.'s were sometimes handling several hearings a day. One day we heard the astonishing testimony of the case of Robert Jones. Jones was convicted of committing a gruesome double murder in a tight-knit community in rural Illinois. The audience listened rapt to several tearful testimonies of grieving family members of the victims. The next half hour featured the unexpected counter-testimony of the victim's neighbor, Jones' mother, who asked forgiveness of the family she had known her whole life. To everyone's amazement, the father of the victim replied directly to Jones' mother, breaking down as he described his futile attempts to try to forgive Jones' actions. And this was just one of 166 stories.

The only people who were conspicuously absent from the hearings were the Death Row prisoners themselves, who were not granted access to their own clemency hearings. As documentary filmmakers, we felt that a major piece of the story was missing. The protagonists themselves, the very people whose fate the Governor was agonizing over, were invisible to our cameras. We needed to get permission to film inside the prison, to see these central characters and hear their voices. 
Getting permission to film inside prison is never easy. The rules for filming in a prison vary with each institution. In addition to whatever the stated rules are, the warden or corrections official responsible for publicity tends to have broad powers to grant or deny access at their discretion. In our experience, if the persons in charge didn't like the sound of your film project, they could deny you indefinitely.

In Illinois, however, there was already a lot of media attention on the prisons, and particularly on the prisoners on Death Row. In 2000 and 2001, several highly publicized exonerations of men on Death Row in Illinois had received national television news coverage. And to produce a special show on Illinois death row inmates, Oprah had recently gained access to film a portion of her daytime television show on Death Row. Since the media had been largely critical of flaws in the system, prison officials were on the defensive whenever they received a request to film.

Our Associate Producer, Angela Tucker, took on the responsibility of seeking permission from Illinois prison officials. Most of the time the answer she got was a flat out "no" to whatever she requested. First, we were told that there was a rule that no cameras were allowed on Death Row at all - the Oprah special being the notable exception - which essentially meant that there could be no new media coverage of the 167 people whose fates were in the hands of the deliberating Governor. We tried different tacks, explaining that we were showing all sides of the story, but we were told there was no way around the new "rule" of no cameras on Death Row.

At the same time that Angela was seeking permission to film, we were also scraping up funds to fly back and forth to Chicago in order to follow the Governor's mercurial decision-making process. One day the Governor told a press conference that he had taken the idea of a "blanket" commutation off the table. A couple of weeks later we filmed a historic relay march of exonerated men from all parts of the country through the night from Illinois' "Death House" to the State of Illinois building, where they presented the governor with a petition to commute the sentences of all 167 prisoners from death to life sentences. We had no idea how the story would end, but now we were hooked on it, and determined to follow through until the Governor did make a decision.

The Governor, though, had a deadline, which was his last day in office on January 13, 2003. He had to exercise his executive power before then. This was a relief to us filming, since we had been swept along with the drama of the Governor's deliberations, but didn't have the budget to 
follow it indefinitely. The advocates for commutation, led by the Center for Wrongful Convictions, was also running out of cash in their campaign to win hearts and minds - and specifically the Governor's - with a vision of mercy toward those on Death Row.

On January 11, 2003 we made another trip to Chicago to film Governor Ryan making history when he surprised the world by commuting the sentences of all 167 people on Death Row. We knew then that we had a new opportunity to film with the prisoners whose clemency hearings we had filmed, since the Death Row rule no longer applied.

Angela stayed in touch with her public affairs contact at the Illinois Department of Corrections and found out where the prisoners were transferred once they were moved off Death Row into the general population. Many were sent to other facilities around Illinois. Once we had obtained written permission from the prisoners themselves, the Department of Corrections granted us access to film. Gratefully, we traveled to Illinois one more time, to film interviews about the experiences of the prisoners themselves. Some, like Grayland Johnson and Gabriel Solache, claimed their innocence; others, like Robert Jones freely admitted their guilt. Having these disparate voices enabled us to make a film that documented a fascinating new chapter in the history of capital punishment, one worthy of being compared to the famous Furman v. Georgia case from 30 years earlier. And when the interviews were complete, we came back to New York to combine the stories of the two events into the film that became Deadline.

\section{ABOUT THE AUTHOR}

Katy Chevigny is co-director of Deadline (2004), an Emmy-nominated documentary, which premiered at the Sundance Film Festival and won the Thurgood Marshall Journalism Award. In an unusual acquisition of an independent film by a major television network, NBC broadcast DEADLINE as a primetime special on their Dateline series in 2004. She directed Election Day (2007), which screened at Toronto's Hot Docs Film Festival in 2007, and was broadcast on U.S. public television in 2008. Chevigny is also the co-founder and Executive Director of Arts Engine, Inc., a non-profit that supports, produces, and distributes independent media of consequence. These films and others produced by Big Mouth Films can be found at www. artsengine.net/store. Arts Engine's projects include Media Rights (see www. mediarights.org) and the Media That Matters Film Festival. 